\title{
CONCENTRACIÓN ESPERMÁTICA. ¿NECESITAMOS UN NUEVO VALOR DE REFERENCIA?
}

\author{
Walter Cardona Maya.
}

Grupo Reproducción. Universidad de Antioquia. Medellín. Colombia.

Resumen.- OBJETIVOS: Evaluar las concentraciones espermáticas de individuos fértiles, población general e individuos infértiles en diferentes regiones del mundo.

MÉTODOS: Las concentraciones espermáticas de diferentes estudios según el estado fértil de cada individuo fue evaluada: individuos con fertilidad comprobada, individuos que consultan a una clínica de andrología o centro de infertilidad y población general.

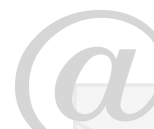

\section{CORRESPONDENCIA}

Walter Cardona Maya

Grupo Reproducción

Universidad de Antioquia

Medellín. A.A. 1226 (Colombia).

wdcmaya@medicina.udea.edu.co

Aceptado para publicar: 24 de abril 2009.
RESULTADO: El promedio de la concentración espermática observada en los estudios para cada grupo fue diferente, siendo menos en los hombres infértiles comparado con los hombres fértiles ( $p>0.001$ ) y la población general ( $p>0.001$ ).

CONCLUSIONES: Basado en este análisis, la concentración normal estaría alrededor de 65 millones por $\mathrm{mL}$. Usando valor de referencia, solo el 25\% de los estudios con hombres infértiles estaría por encima del rango, y el $75 \%$ de los estudios con hombres fértiles estarían en este grupo (>65 × 106 espermatozoides $/ \mathrm{mL}$ ).

Palabras clave: Espermatozoide. Concentración espermática. Valores de referencia. Calidad seminal.

Summary.- OBJECTIVES:To evaluate the sperm count in fertile men, general population, and infertile men in different regions of the world.

METHODS: Sperm counts were recorded according to their fertility status, proven fertility, men recruited from an andrology/infertility clinic, or healthy men

RESULTS: The average of sperm count in the different studies is lower in infertile men that in fertile men ( $p>0.001)$ and in the general population ( $p>0.001$ ).

CONCLUSION: Based on this analysis the normal sperm count is about 65 million per $\mathrm{mL}$. Using these reference value, only the $25 \%$ of the studies in infertile men are above this value, and the $75 \%$ studies with fertile men (>65 x $106 \mathrm{sperm} / \mathrm{mL})$.

Keywords: Spermatozoa. Sperm count. Reference value. Semen quality. 


\section{INTRODUCCIÓN}

Es universalmente aceptado que el análisis seminal es una prueba fiable que da información sobre el potencial fértil de un individuo, y el conteo espermático es uno de los más importantes y cuantitativo parámetro que se obtiene durante en el análisis espermático. Aunque la Organización Mundial de la Salud (OMS, 1), ha reportado valores normales para el análisis seminal, existen sesgos en estos valores de referencia.

Acorde con Sandler y cols, (2) el valor de referencia original establecido en 1934 para considerar a un hombre incapaz embarazar a una mujer era de menos de 60 millones $/ \mathrm{mL}$. Dos décadas después este valor cambio, y se considero que 50 millones $/ \mathrm{mL}$ era el límite inferior para considerar a un individuo fértil. En 1950, un nuevo valor de referencia fue establecido basado en un estudio de 1000 individuos, y fue reportado que 20 millones $/ \mathrm{mL}$ era el limite inferior debido a que mas del $95 \%$ de los hombres fértiles usados en dicho estudio presentaban valores superiores (3). Adicionalmente, varios autores en diferentes

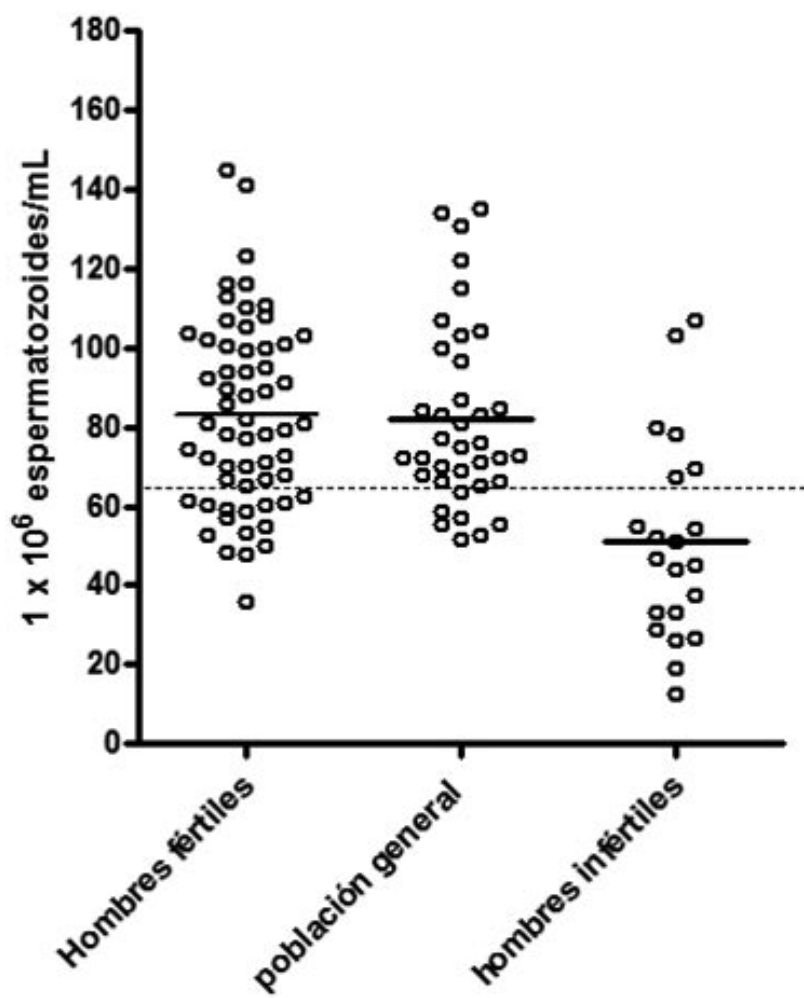

FIGURA 1. Distribución de los datos en cada grupo. Las medias \pm DS y percentiles $25 \%$ y $75 \%$ fueron 81 \pm 23.7 (62.4 y 100.7), 82.1 $\pm 23.2(66$ y 98.3), y $50.9 \pm 25.7(31$ y 68.18) en hombres fértiles, población general y hombres infértiles, respectivamente. regiones del mundo han intentado determinar el correcto valor para diferenciar entre individuos fértiles e infértiles; por ejemplo, Guzick y cols, (4) observan que los individuos fértiles tienen una concentración espermática mayor a 48 millones $/ \mathrm{mL}$, mientras los individuos subfebriles presentan valores menores a 13.5 millones $/ \mathrm{mL}$. Por lo tanto el objetivo de este estudio fue evaluar las concentraciones espermáticas de individuos fértiles, población general e individuos infértiles en diferentes regiones del mundo.

\section{MATERIALES Y MÉTODOS}

En el presente estudio se realizó un análisis de 102 estudios previamente publicados (2 - 103) en los cuales se reportaba la concentración espermática en población general, hombres fértiles e infértiles incluyendo el estudio de Carlsen y cols, (5), en el cual se muestra como la concentración espermática declino significativamente desde 1938 a 1990.

Los datos provenientes de cada estudio fueron documentados acorde con su estado de fertilidad: fertilidad probada (hombres fértiles); hombres reclutados en clínicas de andrología o de infertilidad (hombres infértiles); y hombres sanos (población general); adicionalmente. La concentración espermática fue evaluada en 59 artículos (hombres totales = 14919), en 21 artículos de hombres infértiles (hombres totales $=25963$ ), y en 37 artículos de la población general (hombres totales $=12769$ ) .

La media de los promedios de la concentración espermática en los diferentes grupos estudiados mostro un menor promedio en el grupo de individuos infértiles $(50.9 \pm 25.7)$ comparado con el valor obtenido en el grupo de individuos fértiles $(83 \pm 23.7, p>0.001)$ $y$ en la población general $(82.1 \pm 23.2, p>0.001)$, Figura 1. Adicionalmente, usando el análisis de percentiles se observa que el percentil 25 en el grupo de individuos fértiles y en la población general es similar al percentil 75 en los hombres infértiles, 62.4, 66 and 68.2 , respectivamente.

\section{DISCUSIÓN}

Yo propongo que un nuevo valor de referencia para la concentración espermática podría ser determinado basado en este análisis, el cual estaría alrededor de 65 millones por $\mathrm{mL}$. Usando estos resultados yo estoy seguro que solo el $25 \%$ de los estudios de hombres infértiles no estarían en el grupo de hombres infértiles, y que el $75 \%$ de los estudios realizados con hombres fértiles estarían en el grupo de hombres fértiles. 


\section{CONCLUSIONES}

Por lo tanto, en el fututo este valor de referencia podría ser mas exacto que el valor de referencia actual considerado como normal, es decir más de 20 millones $/ \mathrm{mL}$.

\section{BIBLIOGRAFIA y LECTURAS RECOMENDADAS ( ${ }^{*}$ lectura de interés $y^{* *}$ lectura fundamental)}

**1. WHO. WHO Laboratory Manual for the Examination of Human Semen and Sperm-Cervical Mucus Interaction. Cambridge: Cambridge University Press; 1999.

2. Sandler B. The male factor in human sterility. J Obstet Gynaecol Br Emp. 1953; 60(1):67-75.

3. Macleod J, Gold RZ. The male factor in fertility and infertility. II. Spermatozoon counts in 1000 men of known fertility and in 1000 cases of infertile marriage. J Urol, 1951; 66(3):436-49.

*4. Guzick DS, Overstreet JW, Factor-Litvak P, Brazil CK, Nakajima ST, Coutifaris C, et al. Sperm morphology, motility, and concentration in fertile and infertile men. N Engl J Med, 2001;345(19):138893.

5. Carlsen E, Giwercman A, Keiding N, Skakkebaek NE. Evidence for decreasing quality of semen during past 50 years. BMJ, 1992; 305(6854):60913.

*6. de los Rios J, Cardona WD, Berdugo JA, Correa $\mathrm{C}$, Arenas A, Olivera-Angel M, et al. [Sperm parameters in 113 subjects after recent fatherhood did not correlate with WHO standards]. Arch Esp Urol, 2004; 57(2):147-52.

7. Sobreiro BP, Lucon AM, Pasqualotto FF, Hallak J, Athayde KS, Arap S. Semen analysis in fertile patients undergoing vasectomy: reference values and variations according to age, length of sexual abstinence, seasonality, smoking habits and caffeine intake. Sao Paulo Med J. 2005; 123(4):161-6.

8. Pasqualotto FF, Sobreiro BP, Hallak J, Athayde KS, Pasqualotto EB, Lucon AM. High percentage of abnormal semen parameters in a prevasectomy population. Fertil Steril. 2006; 85(4):954-60.

*9. Sobrero AJ, Rehan NE. The semen of fertile men. II. Semen characteristics of 100 fertile men. Fertil Steril. 1975; 26(11):1048-56.

10. Crazzolara S, Wunder D, Nageli E, Bodmer C, Graf S, Birkhauser MH. Semen parameters in a fertile Swiss population. Swiss Med Wkly. 2007; 137(11-12):166-72.

11. Bahamondes L, Abdelmassih R, Dachs N. Survey of 185 Sperm Analyses of Fertile Men in an Infertility Service. International Journal of Andrology. 1979; 2(1-6):526-33.
12. Jorgensen $\mathrm{N}$, Andersen AG, Eustache F, Irvine DS, Suominen J, Petersen JH, et al. Regional differences in semen quality in Europe. Hum Reprod, 2001; 16(5):1012-9.

*13. Haugen TB, Egeland T, Magnus O. Semen parameters in Norwegian fertile men. J Androl. 2006, 27(1):66-71.

14. Berdugo J, Cardona Maya W, F.T. A-R, Cadavid AP. Semen parameters in fertile men from two South American populations. Arch Esp Urol, 2009; 62 (8): 646-50.

**15. Ombelet W, Bosmans E, Janssen M, Cox A, Vlasselaer J, Gyselaers W, et al. Semen parameters in a fertile versus subfertile population: a need for change in the interpretation of semen testing. Hum Reprod. 1997; 12(5):987-93.

16. Sobowale OB, Akiwumi O. Testicular volume and seminal fluid profile in fertile and infertile males in Ilorin, Nigeria. Int J Gynaecol Obstet, 1989; 28(2):155-61.

17. Badenoch DF, Evans SJ, McCloskey DJ. Sperm density measurement: should this be abandoned? Br J Urol, 1989; 64(5):521-3.

18. Coutinho EM, Melo JF. Clinical experience with gossypol in non-Chinese men: a follow-up. Contraception, 1988; 37(2):137-51.

19. Ibrahim ME, Moussa MA, Pedersen H. Sperm chromatin heterogeneity as an infertility factor. Arch Androl, 1988; 21(2):129-33.

20. Barratt CL, Dunphy BC, Thomas EJ, Cooke ID. Semen characteristics of 49 fertile males. Andrologia, 1988; 20(3):264-9.

21. Chan SY, Wang C. Correlation between semen adenosine triphosphate and sperm fertilizing capacity. Fertil Steril, 1987; 47(4):717-9.

22. Kirei BR. Semen characteristics in 120 fertile Tanzanian men. East Afr Med J, 1987; 64(7):453-7.

23. Aribarg A, Kenkeerati W, Vorapaiboonsak V, Leepipatpaiboon S, Farley TM. Testicular volume, semen profile and serum hormone levels in fertile Thai males. Int J Androl, 1986; 9(3):170-80.

24. Osegbe DN, Amaku EO, Nnatu SN. Are changing semen parameters a universal phenomenon? Eur Urol, 1986; 12(3):164-8.

25. Laufer N, Margalioth EJ, Navot D, Shemesh A, Schenker JG. Reduced penetration of zona-free hamster ova by cryopreserved human spermatozoa. Arch Androl, 1985; 14(2-3):217-22.

26. Swanson RJ, Mayer JF, Jones KH, Lanzendorf SE, McDowell J. Hamster ova/human sperm penetration: correlation with count, motility, and morphology for in vitro fertilization. Arch Androl, 1984; 12 Suppl:69-77.

27. Lewis EL, Brazil CK, Overstreet JW. Human sperm function in the ejaculate following vasectomy. Fertil Steril, 1984; 42(6):895-8.

28. Panidis DK, Asseo PP, Papaloucas AC. Semen pa- 
rameters in 114 fertile men. Eur J Obstet Gynecol Reprod Biol, 1984; 16(6):411-20.

29. Sultan Sheriff D. Setting standards of male fertility I. Semen analyses in 1500 patients--a report. Andrologia, 1983; 15(6):687-92.

30. Schwartz D, Mayaux MJ, Spira A, Moscato ML, Jouannet P, Czyglik F, et al. Semen characteristics as a function of age in 833 fertile men. Fertil Steril, 1983; 39(4):530-5.

31. Osser S, Gennser G, Liedholm P, Ranstam J. Variation of semen parameters in fertile men. Arch Androl, 1983; 10(2):127-33.

32. Stanwell-Smith R, Thompson SG, Haines AP, Ward RJ, Cashmore G, Stedronska J, et al. A comparative study of zinc, copper, cadmium, and lead levels in fertile and infertile men. Fertil Steril, 1983; 40(5):670-7.

33. Borghi MR, Asch RH. Human sperm penetration in bovine cervical mucus. Clinical studies I. J Androl, 1983; 4(5):316-8.

34. Nieschlag E, Lammers U, Freischem CW, Langer $\mathrm{K}$, Wickings EJ. Reproductive functions in young fathers and grandfathers. J Clin Endocrinol Metab, 1982; 55(4):676-81.

35. Abyholm T. An andrological study of 51 fertile men. Int J Androl, 1981; 4(6):646-56.

36. Ladipo OA. Seminal analysis in fertile and infertile Nigerian men. J Natl Med Assoc, 1980; 72(8):785-9.

37. Smith ML, Luqman WA, Rakoff JS. Correlations between seminal radioimmunoreactive prolactin, sperm count, and sperm motility in prevasectomy and infertility clinic patients. Fertil Steril, 1979; 32(3):312-5.

38. Broer KH, Dauber U, Kaiser R, Schumacher GF. The failure to separate human X-and Y-spermatozoa by the millipore filtration technique. J Reprod Med, 1978; 20(2):67-9.

39. Rehewy MS, Thomas AJ, Hafez ES, Brown WJ, Moghissi KS, Jaszczak S. Ureaplasma urealyticum (T-mycoplasma) in seminal plasma and spermatozoa from infertile and fertile volunteers. Eur J Obstet Gynecol Reprod Biol, 1978; 8(5):247-51.

40. Rehan N, Sobrero AJ, Fertig JW. The semen of fertile men: statistical analysis of 1300 men. Fertil Steril, 1975; 26(6):492-502.

41. Nelson CM, Bunge RG. Semen analysis: evidence for changing parameters of male fertility potential. Fertil Steril, 1974; 25(6):503-7.

42. Santomauro AG, Sciarra JJ, Varma AO. A clinical investigation of the role of the semen analysis and postcoital test in the evaluation of male infertility. Fertil Steril,. 1972; 23(4):245-51.

43. Sturde HC, Glowania HJ, Bohm K. [Comparative ejaculate studies in men from sterile and fertile marriages]. Arch Dermatol Forsch, 1971; 241(4):426-37.
44. Eliasson R. Standards for investigation of human semen. Andrologia, 1971; 3:49-64.

45. Freund M, Davis JE. Disappearance rate of spermatozoa from the ejaculate following vasectomy. Fertil Steril, 1969; 20(1):163-70.

46. Rutherford RN, Banks AL, Coburn WA, Klemer RH. Sperm Evaluation as It Relates to , Unplanned Parenthood. Fertil Steril, 1963; 14:521-9.

47. Falk HC, Kaufman SA. What constitutes a normal semen? Fertil Steril, 1950; 1(6):489-503.

48. Farris EJ. The number of motile spermatozoa as an index of fertility in man; a study of 406 semen specimens specimens. J Urol, 1949; 61(6):1099104.

49. Alemnji GA, Thomas KD, Oyelese AO, Ojedije TO. The semen of fertile black males: analysis of 100 consecutive cases. Ann Saudi Med, 2002; 22(1-2):94-7.

50. Saxena P, Misro MM, Chaki SP, Chopra K, Roy S, Nandan D. Is abnormal sperm function an indicator among couples with recurrent pregnancy loss? Fertil Steril, 2008; 90(5):1854-8.

51. Molina J, Castilla JA, Castano JL, Fontes J, Mendoza N, Martinez L. Chromatin status in human ejaculated spermatozoa from infertile patients and relationship to seminal parameters. Hum Reprod, 2001; 16(3):534-9.

52. Zini A, Nam RK, Mak V, Phang D, Jarvi K. Influence of initial semen quality on the integrity of human sperm DNA following semen processing. Fertil Steril, 2000; 74(4):824-7.

53. Giwercman A, Richthoff J, Hjollund H, Bonde JP, Jepson K, Frohm B, et al. Correlation between sperm motility and sperm chromatin structure assay parameters. Fertil Steril, 2003; 80(6):1404-12.

54. Hoshi K, Katayose H, Yanagida K, Kimura Y, Sato A. The relationship between acridine orange fluorescence of sperm nuclei and the fertilizing ability of human sperm. Fertil Steril, 1996; 66(4):634-9.

55. Zini A, Kamal K, Phang D, Willis J, Jarvi K. Biologic variability of sperm DNA denaturation in infertile men. Urology, 2001; 58(2):258-61.

56. Cummins JM, Pember SM, Jequier AM, Yovich JL, Hartmann PE. A test of the human sperm acrosome reaction following ionophore challenge. Relationship to fertility and other seminal parameters. J Androl, 1991; 12(2):98-103.

57. Liu DY, Stewart T, Baker HW. Normal range and variation of the zona pellucida-induced acrosome reaction in fertile men. Fertil Steril, 2003; 80(2):384-9.

58. Zavos PM, Zarmakoupis-Zavos PN, Correa JR, Aslanis P, Zarmakoupis CN. Assessment of two devices for in vitro preparation of human sperm. Arch Androl, 2000; 45(2):85-90.

59. Carrell DT, Liu L, Peterson CM, Jones KP, Hatasaka HH, Erickson L, et al. Sperm DNA frag- 
mentation is increased in couples with unexplained recurrent pregnancy loss. Arch Androl, 2003; 49(1):49-55.

60. Menkveld R, Wong WY, Lombard CJ, Wetzels AM, Thomas CM, Merkus HM, et al. Semen parameters, including WHO and strict criteria morphology, in a fertile and subfertile population: an effort towards standardization of in-vivo thresholds. Hum Reprod, 2001; 16(6):1165-71.

61. Auger J, Jouannet P. Evidence for regional differences of semen quality among fertile French men. Federation Francaise des Centres d'Etude et de Conservation des Oeufs et du Sperme humains. Hum Reprod, 1997; 12(4):740-5.

62. Baba K, Nishida T, Yoshiike M, Nozawa S, Hoshino T, Wamoto T. Current status of reproductive function in Japanese fertile men: international collaborative project on a study of partners of pregnant women. Int J Androl, 2000; 23 Suppl 2:54-6.

63. Meeker JD, Barr DB, Hauser R. Human semen quality and sperm DNA damage in relation to urinary metabolites of pyrethroid insecticides. Hum Reprod, 2008; 23(8):1932-40.

64. Chen Z, Godfrey-Bailey L, Schiff I, Hauser R. Impact of seasonal variation, age and smoking status on human semen parameters: The Massachusetts General Hospital experience. J Exp Clin Assist Reprod, 2004; 1(1):2.

65. Ozgur K, Isikoglu M, Seleker M, Donmez L. Semen quality of smoking and non-smoking men in infertile couples in a Turkish population. Arch Gynecol Obstet, 2005; 271(2):109-12.

66. Juarez Bengoa A, Fernandez Larios JP, Rojas Ruiz JC, Silvestre Tomassoni JR, Villanueva Diaz $\mathrm{CA}$, Arias Hernandez $\mathrm{J}$, et al. [Changes in a semen analysis related to spontaneous pregnancy in patients with infertility history]. Ginecol Obstet Mex, 2006; 74(1):48-54.

67. Chukudebelu WO. Seminal indices in infertile Nigerian men. . Trop J Obstet Gynaecol, 1981; 2:47.

68. Agbaje IM, Rogers DA, McVicar CM, McClure N, Atkinson AB, Mallidis C, et al. Insulin dependant diabetes mellitus: implications for male reproductive function. Hum Reprod, 2007; 22(7):1871-7.

69. Martini AC, Molina RI, Tissera AD, Ruiz RD, Fiol de Cuneo M. Analysis of semen from patients chronically treated with low or moderate doses of aspirin-like drugs. Fertil Steril, 2003; 80(1):221-2.

70. Paasch U, Grunewald S, Fitzl G, Glander HJ. Deterioration of plasma membrane is associated with activated caspases in human spermatozoa. J Androl, 2003; 24(2):246-52.

71. Cocuzza M, Athayde KS, Agarwal A, Sharma R, Pagani R, Lucon AM, et al. Age-related increase of reactive oxygen species in neat semen in heal- thy fertile men. Urology, 2008; 71(3):490-4.

72. Andolz P, Bielsa MA, Vila J. Evolution of semen quality in North-eastern Spain: a study in 22,759 infertile men over a 36 year period. Hum Reprod, 1999; 14(3):731-5.

73. Berdugo J, Correa C, De los Rios J, Olivera-Angel M, Cadavid AP. Perfil espermático de un grupo de pacientes y de voluntarios en Medellín - Colombia. Urología Colombiana, 2000; IX(2):37-42.

74. Li Y, Lin H, Ma M, Li L, Cai M, Zhou N, et al. Semen quality of 1346 healthy men, results from the Chongqing area of southwest China. Hum Reprod. 2008 Dec 1.

75. Paasch U, Salzbrunn A, Glander HJ, Plambeck K, Salzbrunn H, Grunewald S, et al. Semen quality in sub-fertile range for a significant proportion of young men from the general German population: a co-ordinated, controlled study of 791 men from Hamburg and Leipzig. Int J Androl, 2008; 31(2):93-102.

76. Lopez Teijon M, Garcia F, Serra O, Moragas M, Rabanal A, Olivares R, et al. Semen quality in a population of volunteers from the province of Barcelona. Reprod Biomed Online, 2007; 15(4):43444.

77. Jorgensen N, Carlsen E, Nermoen I, Punab M, Suominen J, Andersen AG, et al. East-West gradient in semen quality in the Nordic-Baltic area: a study of men from the general population in Denmark, Norway, Estonia and Finland. Hum Reprod, 2002; 17(8):2199-208.

78. Punab M, Zilaitiene B, Jorgensen N, Horte A, Matulevicius V, Peetsalu A, et al. Regional differences in semen qualities in the Baltic region. Int $\mathrm{J}$ Androl, 2002; 25(4):243-52.

79. Junqing W, Qiuying Y, Jianguo T, Wei Y, Liwei B, Yuxian L, et al. Reference value of semen quality in Chinese young men. Contraception, 2002; 65(5):365-8.

80. Bonde JP. Semen quality and sex hormones among mild steel and stainless steel welders: a cross sectional study. Br J Ind Med, 1990; 47(8):508-14.

81. Shrivastav P, Swann J, Jeremy JY, Thompson C, Shaw RW, Dandona P. Sperm function and structure and seminal plasma prostanoid concentrations in men with IDDM. Diabetes Care, 1989; 12(10):742-4.

82. Welch LS, Schrader SM, Turner TW, Cullen MR. Effects of exposure to ethylene glycol ethers on shipyard painters: II. Male reproduction. Am J Ind Med, 1988; 14(5):509-26.

83. Giblin PT, Poland ML, Moghissi KS, Ager JW, Olson JM. Effects of stress and characteristic adaptability on semen quality in healthy men. Fertil Steril, 1988; 49(1):127-32.

84. Rasmussen K, Sabroe S, Wohlert M, Ingerslev HJ, Kappel B, Nielsen J. A genotoxic study of me- 
tal workers exposed to trichloroethylene. Sperm parameters and chromosome aberrations in lymphocytes. Int Arch Occup Environ Health, 1988; 60(6):419-23.

85. Wang C, Chan SY, Leung A, Ng RP, Ng M, Tang LC, et al. Cross-sectional study of semen parameters in a large group of normal Chinese men. Int $\mathrm{J}$ Androl, 1985; 8(4):257-74.

86. Heussner JC, Ward JB, Jr., Legator MS. Genetic monitoring of aluminum workers exposed to coal tar pitch volatiles. Mutat Res, 1985; 155(3):14355.

87. Levin RM, Latimore J, Wein AJ, Van Arsdalen KN. Correlation of sperm count with frequency of ejaculation. Fertil Steril, 1986; 45(5):732-4.

88. Handelsman DJ, Conway AJ, Boylan LM, Turtle JR. Testicular function in potential sperm donors: normal ranges and the effects of smoking and varicocele. Int J Androl, 1984; 7(5):369-82.

89. Tjoa WS, Smolensky MH, Hsi BP, Steinberger E, Smith KD. Circannual rhythm in human sperm count revealed by serially independent sampling. Fertil Steril, 1982; 38(4):454-9.

90. Hamill PV, Steinberger E, Levine RJ, RodriguezRigau LJ, Lemeshow S, Avrunin JS. The epidemiologic assessment of male reproductive hazard from occupational exposure to TDA and DNT. J Occup Med, 1982; 24(12):985-93.

91. Meyer CR. Semen quality in workers exposed to carbon disulfide compared to a control group from the same plant. J Occup Med, 1981; 23(6):435-9.

92. Roy S, Chatterjee S. Studies with cyproterone acetate for male contraception. J Steroid Biochem, 1979; 11(1B):675-80.

93. Nikkanen V. The effects of vasectomy on viscosity, $\mathrm{pH}$ and volume of semen in man. Andrologia, $1979 ; 11(2): 123-5$
94. Bhushan S, Pandey RC, Singh SP, Pandey DN, Seth P. Some observations on human semen analysis. Indian J Physiol Pharmacol, 1978; 22(4):3936.

95. Polakoski KL, Zahler WL, Paulson JD. Demonstration of proacrosin and quantitation of acrosin in ejaculated human spermatozoa. Fertil Steril,1977; 28(6):668-73.

96. Glaub JC, Mills RN, Katz DF. Improved motility recovery of human spermatozoa after freeze preservation via a new approach. Fertil Steril, 1976; 27(11):1283-91.

97. Zimmerman SJ, Maude MB, Moldawer M. Freezing and Storage of Human Semen in 50 Healthy Medical Students. A Comparative Study of Glycerol and Dimethylsulfoxide as a Preservative. Fertil Steril, 1964; 15:505-10.

98. Lampe EH, Masters WH. Problems of male fertility. II. Effect of frequent ejaculation. Fertil Steril, 1956; 7(2):123-7.

99. Robles GG. Estudio del liquido espermatico. Arch Peruanos Patol Clin, 1947; 1:166-8.

100. MacLeod J, Heim LM. Characteristics and variations in semen specimens in 100 normal young men. J Urol, 1945; 54:474-82.

101. Hotchkiss RS. Factors in stability and variability of semen specimens. J Urol, 1941; 45:875-88

102. Stutz G, Zamudio J, Santillan ME, Vincenti L, de Cuneo MF, Ruiz RD. The effect of alcohol, tobacco, and aspirin consumption on seminal quality among healthy young men. Arch Environ Health, 2004; 59(11):548-52.

103. Richthoff J, Rylander L, Hagmar L, Malm J, Giwercman A. Higher sperm counts in Southern Sweden compared with Denmark. Hum Reprod, 2002; 17(9):2468-73. 